\title{
Correlation Between Memory Ability and Grades Achievement in Different Learning Methods Among Medical Students at Universitas Islam Negeri Alauddin Makassar
}

\author{
Syatirah Jalaluddin ${ }^{1}$ Trisnawaty $^{2,}{ }^{*}$ Rista Suryaningsih ${ }^{3}$ Rosdianah Rahim ${ }^{4}$ \\ ${ }^{I}$ Department of Pediatrics, School of Medicine, Universitas Islam Negeri Alauddin Makassar \\ ${ }^{2}$ Medical Education Unit, School of Medicine, Universitas Islam Negeri Alauddin Makassar \\ ${ }^{3}$ Medical Education Unit, School of Medicine, Universitas Islam Negeri Alauddin Makassar \\ ${ }^{4}$ Department of Community Medicine, School of Medicine, Universitas Islam Negeri Alauddin Makassar
}

"Corresponding author.Email: trisna.waty@uin-alauddin.ac.id

\begin{abstract}
Memory is a part of humans' potential intelligence, which can be measured by using a memory test. Memory test is designed to understand an individual's ability to repeat given information and to analyze them into complex and valuable information. This study is aimed at discovering the correlation between students' memory ability and their grades achievement in different learning methods at the School of Medicine, Universitas Islam Negeri (UIN) Alauddin Makassar. This research was conducted by involving 147 students out of 248 students. The final grades were achieved in three types of learning methods namely offline, online, and blended learning. The memory ability was assessed by using the Intelligenz Structure Test (IST) instrument, in which a memory subtest was given to each student at the beginning of the semester. The study showed no correlation between the test result and blended learning or online learning, with a p-value of 0,526 and 0,827 , respectively. However, a significant correlation was found between the test result and offline learning with a p-value of 0,000 (correlation coefficient 0,406 ). In addition, a correlation was also found between the test result with the year of students' registration and their entrance route, with p-value 0.000 and 0.009 , respectively. The results of this study indicated two things. The first, offline learning method is still really needed by the medical students. The second, blended learning method has significantly increased the students' grades. Assessing the memory ability of the medical students and understanding their needs for appropriate learning method positively influence the learning outcomes.
\end{abstract}

Keywords: Memory ability, learning methods, blended learning.

\section{INTRODUCTION}

Memory is the ability to record, to combine and to store information from every sense, thought, feeling and action to be recalled when they are necessary. In addition, learning method refers to any activity which is deliberately carried out to help the learning process of a group of students to achieve certain learning objectives $[2,4]$. In this regard, there are at least three kinds of learning methods, i.e. offline learning, online learning as well as blended learning.

Through the learning methods, students are given knowledge which is reconstructed as new knowledge and 
is finally stored in their memory This means that the process of gaining new knowledge involves a memory system referred to as the cognitive system. In transferring knowledge to a group of students in pedagogical activities, teachers ideally need to consider the students' memory ability in planning and determining the most appropriate teaching method since employing such a method plays an essential role in achieving the learning outcomes, especially in a higher education level [5]. The outbreak of covid-19 pandemic has caused enormous changes in our daily activities, including the pedagogical process, in which the conventional face to face method cannot be used anymore due to the lockdown of almost all educational institutions in Indonesia since March 2020. Until today, the government of Indonesia still prohibits the use of the face to face teaching method at schools and universities, but recommends the use of online one instead.

\subsection{Memory Ability}

According to Shiffrin and Atkinson (1969) [20], memory is divided into three categories; (1) sensory memory that is the main component which receives sensory information. This memory transforms information in the form of stimulus or signals which initially function to provide perception and identification of information. The memory consists of recipients and information transmitters which can only process a limited amount of information. (2) short term memory or working memory is responsible for organizing information, providing the interpretation of information and forming knowledge stored in long-term memory. The capacity of this memory can only store or hold information for a short period of time. Besides, Fielding (1999) [9] asserts that working memory can only store approximately 5 to 9 elements of information at one time. In other words, it has limited capacity and ability to process information simultaneously. Nevertheless, the working memory will have longer storage capacity when the incoming information is mixed that it can quickly be well received by the sensory memory. (3) long-term memory (LTM) is a tool for storing knowledge permanently. It means that knowledge can be stored for a long period of time and can be recalled. This memory can store declarative, procedural and conditional information [6]. Hence, memory ability plays an important role in the learning process for medical department students, especially those who learn during the Covid-19 pandemic, where they are required to learn online with the support of internet access and sufficient technological devices.

In a nut shell, the learning method used in the medical study program requires adaptation and development. Face-to-face learning method in the classroom which involves teachers and students in one classroom has to be shifted to a more adaptive and relevant method to the current pandemic situation. Consequently, the use of technology and internet-based learning method is a must, in which the internet serves as a learning environment, computers serve as learning media, and learning management system is adapted the current situation for the sake of increasing the learning outcomes.

\subsection{Intelligenz Structure Test (IST)}

Intelligenz Structure Test (IST) is an intelligence test instrument developed by Rudolf Amthaeur at Frankfurt Main Germany in 1953 and has been adapted in Indonesia. The test is used for those 12 up to 60 years old. The IST is developed based on the theory of intelligence which states that intelligence is a gestalt consisting of significantly interconnected $[11,12]$. Intelligenz Structure Test (IST) contains 9 subtests, among other things; Satzerganzung (SE), given to complete sentences, Wortauswahl (WA), given to complete words, Analogien (AN), given to identify synonyms for words, Gemeinsamkeiten (GE), given to share characteristic, Rechhenaufgaben (RA ) given to assess ability to count, Zahlenreihen (SR) given to set series of numbers, Figurenauswahl (FA) given to test ability to choose a shape, Wurfelaufgaben (WU) given to complete a block exercise, and Merkaufgaben (ME) given to complete a symbol exercise. Presentation of the IST test takes approximately 90 minutes, which can be done individually or classically. The final score will show the amount of long term memory, and correlate well with the intelligence. IST can be used for measuring specific intelligence, such as verbal intelligence in subtest 1 to 4 , numerical intelligence in subtest 5 and 6 , figural intelligence in subtest 7 and 8 , also memory intelligence in subtest 9 [1].

\subsection{Learning Methods; offline learning, online learning and blended learning}

In the last decade, the learning methods have gone through gradual development, in which some learning methods are combined to form alternative methods which are relevant to the students' needs and the current situations. One form of the combination is the alignment between face-to-face learning method and virtual learning method which is here called as blended learning method [19]. Blended learning provides not only pedagogical instructions (e.g. learning activities, tasks, assignments, and tests) via the internet to students, but also the administration of attendance records from which teachers, students as well as school staffs interact one another by using the Information Technology (IT) system. School staffs in this context are responsible for ensuring the continuity of learning via the internet and repair all technical problems during teaching [7]. In addition, Blended learning method is also supported by virtual facilities such as online peer discussions, web engine searches, information from blogs, learning management system's software, and various learning media, from the use of animation, teaching videos, or face-to-face online meetings. In short, this method provides diverse supporting facilities which enable interactions between students and teachers in pedagogical practices virtually and this interactions 
potentially stimulates students to learn. Learning theory reveals that the more senses stimulated during the learning process, students' memory will also increase [16].

During the Covid 19 pandemic, many educators in medical department face considerable challenges in using face to face (offline) teaching method because of social distancing and other health protocols to protect people from the virus spread [8]. In this regard, the most challenging thing as for the educators is the process of carrying out courses in clinical skills trainings. In such situation, the shift from offline to online method is considered as a possible alternative to do the courses [3]. We already have a learning management system which is used before the pandemic, but sudden disruption due to the pandemic has forced teachers and students to change their pedagogical habits such as teaching and learning methods. Such a change must certainly affect the student's ability in learning, including their memory ability to gain knowledge. Therefore, it is essential to study whether or not memory has a significant relationship to the three learning methods. This study specifically examines the correlation between students' memory ability and their grades' achievement after taking a plenty of courses which are presented using the three learning methods at School of Medicine of Universitas Islam Negeri (UIN) Alauddin Makassar.

\section{METHOD}

The study was conducted from March to December 2020, involving all undergraduate students from the second until the fourth year in our School of medicine. The correlational quantitative was used as the method of this study. 147 medical students were randomly selected. They consisted of 29 male and 118 female students. The data were collected by testing their memory ability based on the test results obtained from the IST test. The results of IST were divided into 5 categories, namely: very poor LTM (70-79), poor LTM (80-89), moderate LTM (9099), well LTM (100-109), and very well LTM (> 110). The students' final grades were determined by the end of the semester, by selecting three courses from each class, that represent three different learning methods used during the Covid-19 pandemic. Those learning methods were compared by using the data which were analyzed by using Pearson correlation analysis technique available in SPSS version 22. All results of the data analysis were presented in the form of tables.

\section{RESULTS}

Among the 147 participants, most of them are female students, $118(80,3 \%)$, only 29 students $(19,7 \%)$ are male. Fifty respondents $(35 \%)$ are fourth-year medical students. They majority took entrance exam for admission in the univeristy which was widely recognized as Joint Entrance Selection of State Universities (SBMPTN), which account for 67 students $(45,4 \%)$. Most of the students came from families whose income are higher than 5 million Rupiah per month. Our respondents mostly came from the village and rural area in South Sulawesi and the eastern parts of Indonesia. The characteristics of the respondents in this study can be seen in Table 1 as follows.

Table 1. The Characteristics of Respondents

\begin{tabular}{|c|c|}
\hline Characteristics & $\mathbf{N}(\%)$ \\
\hline $\begin{array}{l}\text { Year } \\
\text { - Second } \\
\text { - Third } \\
\text { - Fourth } \\
\end{array}$ & $\begin{array}{l}49(33,3) \\
48(32,7) \\
50(34) \\
\end{array}$ \\
\hline $\begin{array}{l}\text { Gender } \\
\text { - Male } \\
\text { - Female } \\
\end{array}$ & $\begin{array}{l}29(19,7) \\
118(80,3)\end{array}$ \\
\hline $\begin{array}{l}\text { Entrance examination } \\
\text { - SNMPTN } \\
\text { - SBMPTN } \\
\text { - UMM } \\
\end{array}$ & $\begin{array}{l}38(25,9) \\
67(45,6) \\
42(28,5) \\
\end{array}$ \\
\hline $\begin{array}{l}\text { Parent's income per month } \\
-\leq 5 \text { million Rupiah } \\
->5 \text { million Rupiah }\end{array}$ & $\begin{array}{l}67(45,6) \\
80(54,4)\end{array}$ \\
\hline $\begin{array}{l}\text { Origin } \\
\text { - Rural area } \\
\text { - Urban area }\end{array}$ & $\begin{array}{l}88(59,9) \\
59(40,1)\end{array}$ \\
\hline
\end{tabular}

The memory test and the students' final grades of the courses presented in three learning methods during the Covid-19 pandemic, can be seen in table 2 as follows.

Table 2. Intelligenz Structure Test Result and the Final Score of Each learning Method

\begin{tabular}{lccc}
\multicolumn{1}{c}{ Results } & $\begin{array}{c}\text { Minimal } \\
\text { value }\end{array}$ & $\begin{array}{c}\text { Maximal } \\
\text { value }\end{array}$ & Mean \\
\hline IST & 79 & 128 & 100.47 \\
\hline Blended learning & 22 & 96 & 69.42 \\
\hline Online learning & 35 & 87 & 65.69 \\
\hline Offline learning & 18 & 86 & 70.14 \\
\hline
\end{tabular}

Primary Data, 2020 
Table 3. The Correlation Between Students' Characteristics and IST (Memory Test)

\begin{tabular}{|c|c|c|c|c|c|c|c|c|c|c|c|}
\hline \multirow[t]{2}{*}{ Characteristics } & \multicolumn{2}{|c|}{ Very Poor } & \multicolumn{2}{|c|}{ Poor } & \multicolumn{2}{|c|}{ Moderate } & \multicolumn{2}{|c|}{ Well } & \multicolumn{2}{|c|}{ Very Well } & \multirow[t]{2}{*}{ P ralue } \\
\hline & $\bar{n}$ & $\%$ & $\bar{n}$ & $\%$ & $\bar{n}$ & $\%$ & $\bar{n}$ & $\%$ & $\bar{n}$ & $\%$ & \\
\hline Year & & & & & & & & & & & $0.0000^{4}$ \\
\hline \multirow{3}{*}{$\begin{array}{l}\text { - Second } \\
\text { - Third } \\
\text { - Fourth }\end{array}$} & 1 & 2.0 & 14 & 28.6 & 14 & 28.6 & 16 & 32.3 & 4 & 8.2 & \\
\hline & 0 & 0 & 5 & 10.4 & 28 & 58.3 & 15 & 31.2 & 0 & 0 & \\
\hline & 0 & 0 & 4 & 8 & 7 & 14 & 15 & 30 & 24 & 48 & \\
\hline Gender & & & & & & & & & & & 0.971 \\
\hline \multirow{2}{*}{$\begin{array}{l}\text { - Male } \\
\text { - Female }\end{array}$} & 0 & 0 & 5 & 17.2 & 10 & 34.5 & 8 & 27.6 & 6 & 20.7 & \\
\hline & 1 & 0.8 & 18 & 15.3 & 39 & 33.1 & 38 & 32.2 & 22 & 18.6 & \\
\hline $\begin{array}{l}\text { Entrauce } \\
\text { examination }\end{array}$ & & & & & & & & & & & $0.00 g^{*}$ \\
\hline \multirow{3}{*}{$\begin{array}{l}\text { - SNMPTN } \\
\text { - SBMPTN } \\
\text { - UMM }\end{array}$} & 1 & 2.6 & 7 & 18.4 & 18 & 47.4 & 9 & \multirow{3}{*}{$\begin{array}{c}23 . \\
7 \\
41.8 \\
21.4\end{array}$} & 3 & 7.9 & \\
\hline & 0 & 0 & 6 & 9 & 21 & 31.3 & 28 & & 12 & 17.9 & \\
\hline & 0 & 0 & 10 & 23.8 & 10 & 23.8 & 9 & & 13 & 31 & \\
\hline $\begin{array}{l}\text { Parent's income } \\
\text { (Rupiah) }\end{array}$ & & & & & & & & & & & 0.491 \\
\hline \multirow{2}{*}{$\begin{array}{l}-\leq 5 \text { million } \\
->5 \text { million }\end{array}$} & 1 & 1.5 & 13 & 19.4 & 22 & 32.8 & 21 & 31.3 & 10 & 14.9 & \\
\hline & 0 & 0 & 10 & 12.5 & 27 & 33.8 & 25 & 31.2 & 18 & 22.5 & \\
\hline Origin & & & & & & & & & & & 0.153 \\
\hline \multirow{2}{*}{$\begin{array}{l}\text { - Urban area } \\
\text { - Rural area }\end{array}$} & 0 & 0 & 8 & 13.6 & 23 & 39 & 13 & 22 & 15 & 25.4 & \\
\hline & 1 & 1.1 & 15 & 17 & 26 & 29.5 & 33 & 37.5 & 13 & 14.8 & \\
\hline
\end{tabular}

Primary Data, 2020

Chi-square test

The correlation between student's year, gender, entrance process, parents' income, and their origin with the result of IST or memory test can be seen in table 3 . Based on the chi-square test, we found that the memory test result correlates to students' year (the period of their study) and their entrance process, with a p-value of 0.000 and 0.009 , respectively.

\section{Correlation Test}

Pearson correlation test was used to analyse the correlation between the learning methods and students' grades after taking memory tests. This study revealed that there was no correlation between the scores of students' memory tests and blended learning. The significance value was 0.526 ( $p>0.05$ ). Besides, there was no correlation between the students grades in memory tests and online learning. The significance value obtained was 0.827 ( $p>0.05$ ). However, this study found that there was a correlation between students' grades' in memory tests and learning with offline method. The significance value was 0.000 ( $p<0.05)$. The correlation coefficient value was 0.406 , indicating that the relationship between the two variables is moderate. This result also showed positive correlation between the improvement of memory capacity with offline learning methods. This data can be depicted in Table 4 as follows.

Table 4. The Correlation Between Memory Ability and Types of Learning Methods

\begin{tabular}{lccl}
\multicolumn{1}{c}{ Results } & p-value & $\mathbf{r}$ & Interpretation \\
\hline $\begin{array}{l}\text { Blended } \\
\text { learning }\end{array}$ & 0.526 & -0.053 & No correlation \\
\hline $\begin{array}{l}\text { Online } \\
\text { learning }\end{array}$ & 0.827 & -0.018 & No correlation \\
\hline
\end{tabular}

\begin{tabular}{lccc}
\hline $\begin{array}{l}\text { Offline } \\
\text { learning }\end{array}$ & 0.000 & 0.406 & $\begin{array}{c}\text { Positive } \\
\text { correlation }\end{array}$ \\
\hline
\end{tabular}

Primary Data, 2020

Pearson correlation test

\section{DISCUSSION}

Just like other medical institutions in Indonesia, most students are female. Therefore, gender difference in learning processes has always become a great interest to be investigated in a variety of fields. Hill et.al. (2014), in one of their studies describes a consistent working memory network across genders. They concluded that females consistently activate more limbic (e.g., amygdala and hippocampus) and prefrontal structures (e.g., right inferior frontal gyrus). On the other hand, the males activate an inclusive distributed network of more parietal regions [10].

Before the Covid-19 pandemic, the students learned through face-to-face teaching methods. While, the institutions simply provided a learning management system which is specifically focused on managing the administration of the teaching process. There was no special attention given to online learning method. Few students were stimulated to watch tutorial videos or online lectures which has made this method regarded as a supplementary learning method at the time. The courses which require medical skill and competence were taught using the face-to-face method, direct performances and practices. However, the Covid 19 pandemic has changed the education system in medical institutions significantly not only how the courses are done, but also how the teaching-learning methods employed.

Based on the results of analysis, it was found that there was a positive correlation between the use of offline methods and the improvement of students' memory ability. Its significant value is $\mathrm{p}=0.000(\mathrm{p}<0.05)$. The correlation coefficient value is 0.406 , indicating that the relationship between the two variables is moderate. Online and blended learning methods have no relationship with the improvement of the students' memory ability $(p>0.05)$. The $p$-value for the online method is 0.827 ( $p>0.05)$ and the blended method is $0.526(\mathrm{p}>0.05)$.

This analysis indicates that the offline method is the students' most preferable method of learning. In the offline learning method, the intrinsic cognitive load and extrinsic cognitive load are lighter and allow short-term memory and long-term memory to work more efficiently. The ability of sensory memory to accept auditory and visual perception is better in comparison to other methods. This result is obtained because most medical students are not familiar to online learning and blended learning methods yet. This has resulted in the perception that blended learning and online learning still becomes a cognitive load for them. This cognitive load has not been processed by short term memory yet and only becomes information or knowledge stored in long term memory. The result is in line with Retnowaty's research report 
(2008) [18], which states that short term memory has limited capacity when studying lay information. However, short term memory does not have limitations in processing information when initial knowledge is sufficient, available and can be presented automatically. The recall process of the knowledge is determined by an excellent schematic arrangement of knowledge in longterm memory and generated by an organized process of knowledge construction or its frequent use in the shortterm memory. In developing an effective learning method, the intrinsic, extrinsic and constructive cognitive loads are in need of being optimized in order not to exceed the memory capacity of short-term memory. Effective learning methods are those that minimize extrinsic cognitive load or maximize the constructive cognitive load. With this cognitive load management, the students' short term memory can organize the learning materials smoothly $[14,15]$.

In this regard, Mayer (1999) [13] describes that meaningful learning is a learning process which results in students' ability to transfer the knowledge obtained. Thus, an effective learning method is a method that encourages students to build knowledge well that they can use it to solve new problems. Mayer's statement has become a foundation for teachers to design blended learning and online learning as attractive as possible, without making the process as a cognitive burden for the students.

The medical students' learning culture in our university is mostly focused on teacher center, in which the teachers are regarded as the source of knowledge. This learning orientation has made the students consider that offline learning method is the most appropriate learning method. This point of view makes the students more cognitively accept the offline learning method. The students' mindset to understand that they basically are the center of learning is not fully built yet.

In response to the fact, lecturers in medical department at UIN Alauddin have made effort to implement students centered learning. The effort goes into the reconstruction of the teaching and learning methods to be more creative, innovative and exciting ones. For the reason, it is firmly stated in this study that the blended learning method has not been able to attract the attention of the students.

The findings of this study somewhat differ from the study conducted by Rajab (2020) in the College of Medicine (COM) of Alfaisal University in Riyadh, Saudi Arabia, where $62.5 \%$ of the respondents preferred blended learning, compared to offline and online methods. Nevertheless, online learning method still faces some challenges as reported in the literature, including time management, the use of technological devices, highspeed internet access, students' assessment, communication, and the lack of in-person interaction [17]. Nonetheless, the offline learning method is still really needed by medical students. Improving the teaching method in blended learning will significantly increase the students' memory ability and enable us to reach the learning outcome as expected.

\section{CONCLUSION}

The learning method in a medical institution still requires face-to-face teaching, especially for medical skill based courses. However, blended learning has widely developed during the pandemic and became more creative with the use of advanced technological devices. The institution needs to assess the students' memory ability, understand their needs, adapt to new technologies, and create innovative teaching methods which enable the improvement of the learning outcomes.

\section{AUTHORS' CONTRIBUTIONS}

Trisnawaty designed and performed the experiments with the help of Rista Suryaningsih. Rosdianah Rahim performed the analysis and verified the analytical methods. Syatirah Jalaluddin wrote and translated the manuscript in consultation with other authors.

\section{REFERENCES}

[1] Anastasi, A. \& Urbina, S. 2010. Psychological Testing. PT. Indeks. Jakarta.

[2] Anderson J. R., 1995. Learning and Memory-An Integrated Approach. New York: John Wiley \& Sons, Inc.

[3] Bachman et al., 2020. Digital Teaching and Learning of Surgical Skills (not only) During The Pandemic: A Report on A Blended Learning Project. GMS Journal for Medical Education 2020, vol. 37(7).

[4] Bhinnety, M., Sugiyanto dan M. Pudjono. 1994. Pengaruh Intensitas Kebisingan Terhadap Memori Jangka Pendek. Jurnal Psikologi, XXI, 1, Juni, 2838.

[5] Bhinnety, M. Sugiyanto. 1998. Memori Jangka Pendek dalam Situasi Bising, Ditinjau dari Aspek Tes Memori Langsung dan Tak Langsung. Jurnal Berkala Penelitian Pasca Sarjana UGM, 11 (1A), Februari, 79-104.

[6] Bruning, R. H., Scraw, G. J., Norby, M. N., \& Ronning, R. R. (2004). Cognitive Psychology and Instruction (4 ed.). Ohio: Prentice Hall. 
[7] Ellaway, R. \& Masters, K. 2008. E-learning in Medical Education. Part 1: Learning, teaching and assessment. AMEE GUIDE Journal (455-473)

[8] Eva and Anderson, 2020. Medical Education Adaptations: Really Good Stuff for educational transition during a pandemic. Med Educ. 2020;54(6):494. doi: 10.1111/medu.14172. - DOI PubMed

[9] Fielding. 1999. The Memory Manual. Jakarta. PT. Buana Ilmu Populer.

[10] Hill, A. C., Laird, A. R., Robinson, J. L. 2014. Gender Differences in Working Memory Networks: A BrainMap meta-analysis. Biological Psychology. Volume 102. Available at https://www.sciencedirect.com/science/article/abs/ pii/S0301051114001185.

[11] Jones, S. 2016. Tes Psikologi. PT. Indeks. Jakarta.

[12] Kumolohadi, R. and Suseno, M. N. 2012. Intelligenz Struktur Test dan Standard Progressive Matrices: (Dari Konsep Inteligensi yang Berbeda Menghasilkan Tingkat Intelegesi yang Sama). Jurnal Inovasi dan Kewirausahaan. Volume 1. Nomor 2. Available at https://journal.uii.ac.id/ajie/article/view/2825/2578

[13] Mayer, R. 1999. The Promise of Educational Psychology: Teaching for Meaningful Learning (Vol. 2). USA: Merill - Prentice Hall.

[14] Miller, R. 1956. The Magic Number of Seven Plus or Minus Two: Some Limits on Our Capacity for Processing Information. Psychological Review, 63, $81-97$

[15] Pass, F., Renkl, A., \& Sweller, J. 2004. Cognitive Load Theory: Instructional Implications of the Interaction between Information Structures and Cognitive Architecture. Instructional Science, 32(12), 1-8

[16] Rahmi, U. 2016. Desain sistem pembelajaran blended learning: upaya peningkatan kualitas pendidikan di Indonesia. Indoensia Scholar JournalInsight. Available http://repository.unp.ac.id/15879/

[17] Rajab, M.H., Gazal, A. M., Alkanta, A. 2020. Challenges to online Medical Education During the Covid-19 Pandemic. Cureus 12 (7):, e8966. DOI 10.7759/cureus.89966.
[18] Retnowati, E., Sweller, J. \& Ayres, P. (2008). Group Work Settings: Worked Example Vs. Problem Solving. Online Proceeding of International Conference on Cognitive Load Theory 2008, Retrieved at http://www.uow.edu.au/conferences/ Cognitive_Load_Theory_2008/program.html

[19] Rice \& Mckendree, 2014. Understanding Medical Education: Evidence, Theory and Practice, $\left(2^{\text {nd }}\right.$ edition). USA: Wiley Blackwell,

[20] Shiffrin, R. M., \& Atkinson, R. C. 1969. Storage and Retrieval Process in Long Term Memory. Psychological Review, 76(2), 179-193 